\title{
Analysis of the Leadership Influence on Organizational Climate, Organizational Commitment and Work Behavior of National Program for Urban Community Empowerment in Lombok
}

\author{
Lalu Suparman Mukmin Suryatni* Surati \\ Faculty of Economics and Business, University of Mataram, Indonesia
}

\begin{abstract}
This research aims: 1) to analyze and find the significant direct influence of leadership on organizational climate, organizational commitment, and work behavior; 2) to analyze and find the significant direct influence of organizational climate and organizational commitment on work behavior. Method of data collection used was purposive sampling method. Population for this research is all the supporting Urban PNPM (PNPM Perkotaan) spread between four Regencies/ City on Lombok Island. The amount of population is 116 supporting persons. The sample of the respondent is 15 persons in each Regency/City, totaling a respondent sample of 60 persons. Data analyses tool used is Partial Least Square using Smart PLS 2.0 program. Research findings are: (1) there is a relatively high, positive and significant effect of leadership on organizational climate; (2) there is a relatively high, positive and significant effect of leadership on organizational commitment; (3) there is relatively small, positive, and significant effect of leadership on work behavior; (4) there is a relatively high, positive and significant effect of organizational climate on work behavior; (5) there is a high, positive, and significant effect of organizational commitment on work behavior.
\end{abstract}

Keywords: Leadership, Organizational Commitment, Organizational Climate, Work Behavior, PNPM. JEL Classification: $\mathrm{H} 8$

DOI: $10.7176 / \mathrm{EJBM} / 12-26-08$

Publication date:September $30^{\text {th }} 2020$

\section{Introduction}

The National Program for Community Empowerment (PNPM) is one of the government programs organized for community empowerment in poverty reduction efforts, especially in urban areas. In West Nusa Tenggara Province, this program has been implemented since 2004 in 6 (six) districts / cities i.e. Mataram, West Lombok, Central Lombok, East Lombok, Sumbawa and Bima.

Concern with PNPM implementation, support from a competent and professional personnel who have the ability to communicate and cooperate with both colleagues and the community who became the target of empowerment is needed. The assistance those support the PNPM program spread out in West Nusa Tenggara, both heads / coordinators and implementers in the field (assistant or program facilitator) amounted 156 people consisting of 5 City Coordinators, 33 Assistant Coordinators of independent City, and 118 supervisors.

Any assistance has their respective roles with tasks and functions to run. All activities are carried out in accordance with standard procedures which is established and agreed. The output achieved has been standardized. The field officers run the activities by getting direct monitoring from the coordinator so they get the evaluation and feedback. The success of the field implementation team of PNPM, in carrying out the activities and achieving the expected performance or output, can be determined by many factors, like the personnel themselves, such as the ability, competence, the commitment of personnel in receiving, running tasks, and the organization factors, such as organizational climate and leadership factors.

A study by Hanafiah (2016) on PNPM in West Nusa Tenggara indicates that there are some personnel are unable to complete the tasks given, either in terms of finishing time or quality standards such as the lack of community understanding of the activities that impacted to the lack of community support, skills of assisted communities in the administration and technical implementation of the activities, beside of that there are still accompanying personnel who did not work by following the agreement of applicable rules. This may be due to the ability, competence, or commitment of the personnel themselves.

The leadership pattern applied by the city coordinator (Korkot) can determine the performance of facilitators or supervisors. There are several other phenomena that can be expressed like there are many supervisors who complain about the patterns applied by Korkot, sometimes its seen from less disciplined in performing tasks that are assigned as a supervisor. Based on the observation, the existing Karkot leadership in PNPM Mandiri Urban is not effective yet, it seen from Korkot leadership can not divided the tasks on all the existing jobs and less in giving praise to the results of the personnel of PNPM Mandiri Urban supervisor so that it impacts on the low performance of individual in organization (Hanafiah, 2016).

The performance of a person in the organization can be seen from the output or from the working behavior, which got a direct assessment equally by the supervisor or the boss. Performance or individual achievement in 
terms of the process in the form of work behavior can be influenced by many factors such as;

Ability, motivation and opportunities or chance (Robbin, 2006). Then Gibson (1996) stated that individual work performance is influenced by individual, psychology and organizational factors. According to the opinion of both experts that the performance or work behavior of an individual in the organization can be influenced by many factors including leadership, organizational commitment and organizational climate, which is the subject of this study.

Several previous studies on leadership related to achievement or individual performance, among others: Mamik (2010) Study about the influence of leadership style, on employee performance. The result of his study is leadership style has a significant effect on employee performance, and it can be said that the relationship of leadership style with employee performance is positive and relatively strong enough. Furthermore, Shahab (2010) conducted the study by finding out that there is a significant positive influence of Islamic leadership on Islamic performance. It shows that the better the Islamic leadership, the better the Islamic performance of the employee. If the quality of Islamic leadership is further enhanced, it will give a positive impact on the employee's Islamic performance. Hakim (2012), who conducted a study at Bank Mu'amalat Indonesia Tbk in Central Java. The result of his study is, there is a positive and significant influence of Islamic leadership on the employee's Islamic performance. The results are interpreted if the quality of Islamic leadership can be implemented properly, then the employee's Islamic performance will be better.

In the same year Pradityo, et al (2012) also conducted a study on PT. Telkom Indonesia Semarang; the results of their study indicate that there is a positive and significant influence of leadership on employee performance. Sukardiyono (2013) conducted a study on National Unity (Bakesbang), Politics and Community Protection of Kediri Regency; the results of his study are leadership has a positive and significant effect on employee productivity

While the study conducted by Susanto and Aisiyah (2010); conducted a study at the Land Affairs Office of Kebumen Regency, the results of his study stated that leadership has no significant effect on Employee Performance. Suparman, et al (2013) who conducted a study on State Madrasah Aliyah and State Madrasah Tsanawiyah in Mataram City, found that leadership was relatively small, positive and insignificant in teacher work performance.

Differences in the results of studies among previous researchers, allegedly due to the measurement of leadership variables and unequal performance. Mamik (2010) measures leadership from the style which is applied by the leader. Shahab (2010) takes measurements of leadership variables in terms of educating, giving guidance, advising, and cooperating. Hakim (2012) measures leadership in terms of attributes possessed and demonstrated by leaders, such as the nature of Siddiq, Amanah, Tabliq, and Fathonah. While Suparman, et al (2013) measure the leadership of the operational functions which is run by a leader, that is the delivery of vision, mission, goals and work programs; job ceiling to subordinates; giving orders and direction; motivation and reward; supervision and control.

From the results of the study can be concluded that the measurement of constructive variables (leadership), in terms of indicators used contain elements of weakness. The reaction of the respondents when the data collection is done, the respondent is out of attention to the questionnaire, so that they do not provide an inappropriate response. The other theory said that leadership has a positive influence, which is large and significant to the performance or work behavior of individuals. The reason is leaders have an important role in determining the success or failure in an organization. That is why researchers are more focused and intent to study about the leadership which is related to the work behavior of individuals as subordinates in an organization.

Furthermore, the study about the relation of leadership with an organizational climate that has been done by Fitri and Syamsir. Fitri and Syamsir (2011) conduct a study on State Owned Enterprise (BUMN) PT PLN Branch Solok; indicates that there is a positive and significant influence of leadership style on organizational climate. There no large researcher doing this kind of study that is why researchers interested in conducting a study related to organizational climate.

While the study of the relationship between organizational climate with performance or work achievement has been done by some researchers: Pradityo, et al (2012); conducting a study on PT. Telkom Indonesia Semarang; it shows that the Climate Organization has a positive and significant impact on employee performance. Then Sukardiyono (2013); conducting a study on Bakesbang, Politics and Community Protection of Kediri Regency; shows that Climate organization has a positive and significant effect on employee productivity. Wahyuni (2015); conducting a study on PT. Garuda Indonesia Padang; shows that Organizational Climate on Employee Performance has a positive and significant influence. It is seen from the better organization climate, the higher the employee performance, otherwise the worse organizational climate, the lower the employee performance.

Three studies about the effect of organizational climate on the performance or work productivity, have differences variables measure. The variables indicator of organizational climate and employee performance used by three researchers are different, that is why the team want to study more about the relationship or effect between variables. 
Dealing with the results of the study above, the researchers are interested to review the relationship and effect between variables according to the title proposed. Based on the results of previous studies, the researchers can develop the study in terms of methodology, indicators of each variable and analysis tools used.

The purpose of this study are; 1). To analyze and understand the significant influence of leadership on the organizational climate; 2). To analyze and understand the significant influence of leadership on organizational commitment; 3). To analyze and know the significant influence of leadership on work behavior; 4). To analyze and to know the significant influence of organizational climate on work behavior; and 5). To analyze and to know the significant influence of organizational commitment to work behavior.

\section{Literature Review}

\section{Working Behavior Review}

Behavior is an act or action that can be observed, viewed, measured and assessed. The behavior of a person in an organization is a behavior that is expected or desired by the leadership of the organization where a person is working. Working behavior becomes a tool to measure one's work performance. By evaluating the performance appraisal of Civil Servants, researchers consider it highly representative to assess employer / employee work behavior in an organization. Performance appraisal appears to be directed to control productive work behavior and can be done on the basis of objective, quantifiable, accountable, participatory and transparent principles.

From the system and the procedure of assessment, that there are two main elements that become the assessment of Employee Working Standard (SKP) namely first, Working Objectives consisting of quality, time, and cost. Second, Working Behavior by covering service orientation, integrity, commitment, discipline, cooperation and leadership.

In this study the working behavior of the facilitators in PNPM Mandiri Urban in Lombok Island, viewed from: the timeliness of running the task / serving the community; discipline in work; responsibility for duty; the spirit of completing the task; creativity in work; and politeness interact and communicate with partners, elements of the internal leadership, target communities.

The behavior of assistant work as a facilitator in an organization can be influenced by its leader in this case city coordinator (Korkot) in PNPM Mandiri Urban where they work. Some research results have proved that leadership has a positive and significant impact on working behavior (work performance). Mamik (2010) examines the influence of leadership style, on employee performance. The result of his research that leadership style has a significant effect on employee performance, and it can be said that the relationship of leadership style with employee performance is positive and relatively strong enough.

Suparman, et al (2012) conducted a study with the aim to determine the effect of implementation of Islamic leadership qualities and leadership functions on teacher work performance. The result of the study is that there is a significant influence of leadership on work performance. But surprisingly enough the results of research conducted by Suparman, et al (2013), whose research results have a positive influence, its influence is relatively small and insignificant from leadership to achievement on working. The results do not support the results of previous studies.

While in terms of theoretical expectations, that leadership has a positive influence, great and certainly significant to the performance or work behavior of individuals. This means that by applying good leadership (performing its functions) then subordinate or follower work behavior will be as good as expected. In addition, leadership plays a very important role and determines once the success or failure of an organization to achieve its objectives.

2. Leadership Studies

Opinions of some experts on leadership, used as reference researchers to be analyzed further. Yukl (2005) quotes House at. al. (1999), that leadership is the ability of individuals to influence, motivate, and make others able to contribute to the effectiveness and success of the organization. Yukl himself concludes that leadership is a process for influencing others to understand and agree with what needs to be done and how it is done effectively, as well as a process to facilitate individual and collective efforts to achieve common goals.

Nimran's opinion (2004), that leadership is defined as the process of influencing the behavior of others to behave as will be desired. Implementation of this leadership is not limited to an organization (formal), but can also take place outside the organization, such as non-formal social institutions. The definite element of this definition is that there are leaders, subordinates or followers, influences sourced from power and the desired purpose.

In the implications of leadership that the leader is always in contact with others, who act as subordinates or followers; leaders will use the formal influence and power it has; leaders will want to change the behavior of subordinates or followers; leaders always strive to achieve organizational goals as well as individual goals; and leadership practices are institutionalized (formal).

The writer examines more about leadership in one of the government activities that are collected in the container of the National Program for Urban Community Empowerment in each district City on the island of Lombok. As the leader of an institution will undertake the functions of leadership, in which the functions can be 
carried out effectively when based on the nature of an Islamic leader. The Islamic qualities must be reflected in every function performed by the leader. Leadership behavior in carrying out the leadership function is based on Islamic values such as Shiddiq (true, honest), Amanah (trustworthy, responsible), Tabligh (transparent, communicative), and Fathanah (intelligent, resourceful, knowledgeable).

This study aims to re-examines using leadership indicators that have been studied Suparman, et al (2013). Indicators are: delivery of vision, mission, goals and work program; distribution of job duties to subordinates; giving orders and directives performing tasks or activities; giving motivation and appreciation to subordinates; supervision and control over all activities of the organization.

3. Review Organizational Commitment

Organizational commitment is as a situation where an employee sided with a particular organization to maintain membership in the organization. Robbins (2006) states that high employment involvement means favoring the individual's particular job, while high organizational commitment means favoring the organization that recruits the individual.

Gibson (1996) states organizational commitment is the identification of the sense, engagement, loyalty that workers display in their organizations, commitment is demonstrated by the acceptance of strong beliefs about the values and goals of an organization, as well as a strong impulse to defend itself as a member of the organization. Lutans in Sutrisno (2011) states that employee commitment is a strong desire of employees to become members in a group, a high willingness to the organization and acceptance of the values and goals of the organization. Organizational commitment based on a bond, loyalty or loyalty of employees / employees to the organization so they are willing to work for organizations with values that are held firm together.

From another dimension that Allen and Meyer (1990) and Summers and Acito (2000) in Sutrisno (2011) describe that from the definition of organizational commitment identified three components: 1). affective commitment, a psychological attachment to the organization or the emotional involvement of an individual in his organization; 2). continuance commitment, in the form of a psychological attachment to the organization, that the individual considers the cost and risk of leaving the organization. 3 ). normative commitment, in the form of psychological attachment to the organization, because of the feeling of obligation to maintain and maintain the organization.

There are 7 indicators introduced by Suparman applied within this research (2014) consisting of: 1). pride as members of the organization because of organizational values and goals in line with their expectations, 2). loyalty to leaders and organizations by showing their obedience and obedience in performing their duties, 3 ). willingness to accept job duties, 4). sincerity in working by following the rules and willingness to sacrifice for the organization, 5 ). hope to remain a member of the organization, 6). feel loss leaving the organization and added with one indicator that is 7) equality of vision value, mission, goals and program organization.

4. Organizational Climate Review

Wirawan (2008) and Soborin (2009) in his book quoting Tagiuri and Litwin (1968) in his book "Organizational Climate" stated that the organizational climate is the quality of the internal environment of the organization that (a) is felt and experienced by members of the organization, (b) affecting their behavior and (c) which can be explained in the form of a set of characteristics or attributes of the organization. Sobirin further states that organizational climate is understood as a set of objective organizational conditions; as subjective interpretations of individuals and as the characteristics of an organization.

Wirawan (2008) also cites the opinion of Litwin and Stringer (1968) with his book "Motivation and Organizational Climate" said that the organizational climate is a concept that describes the subjective nature or quality of the organization environment. The elements can be perceived and experienced by members of the organization and reported through appropriate questionnaires. Soborin (2009) also cites the opinion of Litwin and Stringer who said that the climate organization has 9 (nine) dimensions: structure, responsibility, reward, risk, warmth, support, standard, conflict and identity.

To find out the climatic conditions of the organization, Wirawan (2008) states that it can be seen from the physical environment dimensions (workspace, equipment and production processes), social environment (subordinate employee relations, co-workers relationship, customer relations) organizational structure and bureaucracy, resource allocation, working standards and procedures, and leadership).

5. Concepts and Research Hypotheses

The working behavior of co-facilitators in PNPM Urban may be influenced by the leader (in this case the city coordinator), either directly or indirectly. Directly the leader with the authority by instructions and suggestions formally ask the companion to facilitate on certain activities as desired. Indirectly that the leadership can move the companion through the process of fulfilling their needs first or give a certain hope first, and then they do their duty. In addition, leaders can create a good atmosphere in the organization and make the members involved in various activities and able to make members show their loyalty to the organization.

Based on the opinion of some experts and the results of previous studies the research hypothesis can be stated are: 1). leadership has a positive and significant influence directly on the organizational climate; 2). leadership has 
a positive and significant influence directly on organizational commitment; 3). leadership has a positive and significant influence directly on working behavior; 4). organizational climate has a positive and significant influence directly on working behavior and 5). organizational commitment has a positive and significant influence directly on working behavior.

\section{Research Design}

\section{Data Collection}

Method and the data collection technique of this study is the survey sample method. Population in this study is all supervisor or facilitator of PNPM Urban activity in whole of Lombok Island. It located in Mataram City, West Lombok, Central Lombok, and East Lombok. The number of population in the four districts of the city is 116 supervisors. The number of samples is determined by purposive sampling. The number of samples is 60 people, by determining 15 people in each district / city, which is used as study respondents.

\section{Operational Definition}

2. 1. Leadership (X); in this study is the perception or opinion of the respondent, about the attitude and behavior and ability of the leader (Coordinator of City / Korkot) in carrying out its leadership functions. To measure the leadership of City Coordinator / Korkot, the researcher uses indicators such as: (1) Delivery of Vision, Mission, Goals and Work Program; (2) Distribution or distribution of job duties; (3) Giving orders and directives to subordinates; (4) Providing motivation or morale to subordinates; (5) Awarding of subordinate performance; and (6) Supervision and control and feedback. To obtain information or data about all the indicators of leadership, researchers used questionnaires in the form of questionnaires.

2. 2. Organizational Climate (Y1); the meaning of this study is the perception or opinions of respondents, about the state of the internal environment perceived and that affect their performance in the organization. To measure the organizational climate, the researcher uses indicators: (1) Clarity of Assignment Duties and Responsibilities; (2) Clarity of Service Process and Facilitation of target communities; (3) Harmonious relationships with superiors and co-workers; (4) Relationship Social interaction with the target community; (5) Availability of Facilities and Work Equipment; and (6) Resource Distribution and Allocation. To obtain information or data about all organizational climate indicators, the researcher uses questionnaires in the form of a questionnaire.

2. 3. Organizational Commitment (Y2); is the perception or opinion of the respondent, about the attitudes and behaviors related to their involvement as a supervisor or facilitator of PNPM Urban activities in Lombok Island. To measure the organizational commitment of the respondents, the researcher uses some indicators that are: (1) The similarity of vision value, mission, goals and organizational program; (2) Pride to be part of the organization; (3) Loyalty to leaders and organizations; (4) Willingness to accept duties from the leadership of the organization; (5) The willingness to sacrifice for the organization; (6) Hope remains a member of the organization; and (7) Feel the loss of leaving the organization. To obtain information or data on all indicators of organizational commitment, the researcher uses a questionnaire.

2. 4.Work Behavior (Z); which is referred to in this study is the assessment of superior or co-ordinator (Urban / Korkot Coordinator) of PNPM Urban in Lombok Island against the form of actions or deeds that are expected to be done by the facilitators / escort activities in the field in carrying out their job duties. To measure the behavior of the work, the researcher uses some form of work behavior that is: (1) Timeliness of duty / serve the society; (2) Discipline in work; (3) Responsibility for duty; (4) The spirit of completing the task; (5) Creativity in work; and (6) politeness interacts and communicates. To obtain information or data on all working behavior indicators of PNPM Urban supervisor activities, the researcher uses questioners in the form of a questionnaire containing a list of direct supervisor's assessment.

\section{Analytical technique}

\section{1.Descriptive analysis Descriptive}

The analysis is intended to provide an overview of the work behavior of a supervisor who is a member of the field team. In addition, an overview of leadership practices undertaken by the respondent's city coordinator as well as an overview of the organization's climate and organizational commitment of the supervisor.

To describe and analyze the variables of the study, the researcher uses a table analysis of the data frequency or the average score of each variable. The researcher uses Likert scale to collect data with 5 points, ie score $1=$ Very Good, score 2 = Good, score 3 = Fairly Good, score $4=$ Bad and score $5=$ Worse. The scores of each variable are converted according to the nature of the variable. considering that every item of a variable is collected from many respondents, so that the scores average have variety, to make it easier in data processing of each variable or sub-variable can be grouped and converted into the properties of each variable research, as shown in Table 1. 
Table 1: Criteria and categories of study variables

\begin{tabular}{|l|l|l|l|l|}
\hline Score & \multicolumn{4}{|l|}{ VARIABLE CATEGORIES } \\
\hline & Leadership & $\begin{array}{l}\text { Organizational } \\
\text { commitment }\end{array}$ & $\begin{array}{l}\text { Organizational } \\
\text { Climate }\end{array}$ & Behavior \\
\hline$\geq 4.60$ & Very Good & Very High & Very Conducive & Very Good \\
\hline 3.60 to 4.50 & Good & High & Conducive & Good \\
\hline 2.60 to 3.50 & Fairly Good & Fairly Hight & Conducive Enough & Fairly Good \\
\hline 1.60 to 2.50 & Bad & Low & less conducive & Bad \\
\hline$\leq 1.50$ & Worse & Very Low & Not Condusive & Worse \\
\hline
\end{tabular}

Sources: primary data processed

3. 2.Analysis of Partial Least Square (PLS)

Data Analysis Procedure is Smart PLS 2.0.m3. According to Jogiyanto and Abdillah (2009), PLS (Partial Least Square) are: Analysis of structural Equations based on variants that can simultaneously perform testing of measurement models as well as testing structural models. The measurement model is used for validity and reliability test, while the structural model is used for causality test (hypothesis testing with the prediction model). PLS (Partial Least Square) uses the principle component analysis method in the measurement model, for example, the extraction block which is used to see the indicator relationship with its latent construct by calculating the total variance of the common variance, the specific variance and the (error variance. So, the total variant becomes high. According to Hartono (2008) in Jogiyanto and Abdillah (2009) explained that the size of the significance of hypothesis support can be used to compare the T-table and T-statistic value. If T-statistic is higher than the T-table value, the hypothesis is supported or accepted. In this study for a 95 percent confidence level (alpha 95 percent) then the T-table value for the hypothesis one-tailed is $>1.68023$. Analysis of PLS (Partial Least Square) used in this study was conducted using Smar tPLS 2.0.m3.

\section{Instrument Validity}

The instrument of each variable namely: Leadership (X) consists of 6 items, Organizational Climate (Y1) consists of 6 items, Organizational Commitment (Y2) consists of 7 items, and Work Behavior (Z) consists of 6 items. All item of each variable is validated using correlation test product moment. The researcher uses the SPSS program with correlation bivariate. Criteria testing, if the $r$ count is bigger than $r$ table $(r 5 \%(116)=0.316)$ then each item variable is with the following explanation.

4. 1. Test of Instrument Validity

The result of validity and reliability test as shown in Table 2. It shows that the $r$ count of the four variables is more than 0.316 in $r$ table, it can be concluded that each instrument valid.

Table 2. Validity Research Instruments

\begin{tabular}{|l|l|l|l|l|l|l|l|}
\hline \multicolumn{2}{|l|}{$\begin{array}{l}\text { Leadership } \\
(\mathrm{X})\end{array}$} & \multicolumn{2}{l|}{$\begin{array}{l}\text { Climate } \\
(\text { Y1 })\end{array}$} & \multicolumn{2}{l|}{$\begin{array}{l}\text { Organizational } \\
\text { Commitment (Y2) }\end{array}$} & \multicolumn{2}{l|}{$\begin{array}{l}\text { Work Behavior } \\
(\mathrm{Z})\end{array}$} \\
\hline Item & R count & Item & R count & Item & R count & Item & count R \\
\hline X.1 & 0.583 & Y1.1 & 0.530 & Y2.1 & 0.521 & Z.1 & 0.046 \\
\hline X.2 & 0.590 & Y1.2 & 0.792 & Y2.2 & 0.514 & Z.2 & 0.077 \\
\hline X.3 & 0.601 & Y1.3 & 0.563 & Y2.3 & 0.510 & Z.3 & 0.813 \\
\hline X.4 & 0,523 & Y1.4 & 0,645 & Y2.4 & 0.665 & Z.4 & 0.690 \\
\hline X.5 & 0.441 & Y1.5 & 0.338 & Y2.5 & 0.676 & Z.5 & 0.676 \\
\hline X.6 & 0.231 & Y1.6 & 0.580 & Y2.6 & 0.565 & Z.6 & 0.803 \\
\hline & & & & Y2.7 & 0.525 & & \\
\hline
\end{tabular}

Sources: primary data processed

4. 2. Research Reliability

The results of the reliability of the four variables such in in table 3.

Based on table 3., it shows that the value of Cronbach's alpha count for each instrument of research variables is bigger than the standard of Cronbach's alpha $0.60(60 \%)$ so it can be concluded that each research instrument is reliable. 
Table 3. Criteria Research Reliability

\begin{tabular}{|l|l|l|l|l|}
\hline No. & Variable & $\begin{array}{l}\text { Coefficient of } \\
\text { Reliability }\end{array}$ & Limit Value & Criteria \\
\hline 1 & Leadership (X) & 0.821 & 0.600 & Reliable \\
\hline 2 & Organizational Climate (Y1) & 0.838 & 0.600 & Reliable \\
\hline 3 & $\begin{array}{l}\text { Organizational Commitment } \\
\text { (Y2) }\end{array}$ & 0.867 & 0.600 & Reliable \\
\hline 4 & Work Behavior (Z) & 0.915 & 0.600 & Reliable \\
\hline
\end{tabular}

Source: Primary data processed

\section{Finding and Discussion}

\section{Description of the Research Variables}

\section{1.Leadership Variable $(X)$}

Leadership as a form of leader capacity in an effort to influence subordinates so they will behave as the leaders instructed. The meaning of leadership in this study is the subordinates' opinion or perception (facilitator / assistant) toward the attitude and behavior of leaders on the national program of community empowerment in Lombok. Attitudes and behaviors of the leaders can be seen in terms of activities of leaders in carrying out their leadership functions. Through these activities are expected to move subordinates well. However, the opinions of the subordinates or facilitators who were the respondents for the leadership behavior (city coordinator) are shown by the data in Table 4 bellows.

The functions of leadership that is conducted by the coordinator of the city become the companion assessment which becomes six indicators in this study. Overall, the result of the companion which becomes respondents to the leadership of coordinators in each city / regency in Lombok Island shows that the score is 3.76 which is categorized as "good". This means that the coordinators have performed the leadership function well. It is certainly supported by the ability of knowledge, skills and attitudes and behaviors to carry out the duties.

Table 4. Average Score and Leadership Indicator Categories

\begin{tabular}{|l|l|l|l|}
\hline No. & Indicator Leadership & Average Score & Category \\
\hline 1. & Delivering visions, missions, goals and programs & 3.84 & Good \\
\hline 2. & Distributing desk job & 3.80 & Good \\
\hline 3. & Giving orders and directions & 3.76 & Good \\
\hline 4. & Giving work motivation to subordinates & 3.76 & Good \\
\hline 5. & Awarding for the performance of subordinates & 3.67 & Good \\
\hline 6. & Supervision, control and feedback & 3.73 & Good \\
\hline Average Score & 3.76 & Good \\
\hline
\end{tabular}

Source: Primary data processed

The function of leadership that is conducted by the coordinator of the city become the companion assessment which becomes six indicators in this study. Overall, the result of the companion which becomes respondents to the leadership of coordinators in each city / regency in Lombok Island shows that the score is 3.76 which is categorized as "good". This means that the coordinators have performed the leadership function well. It is certainly supported by the ability of knowledge, skills and attitudes and behaviors to carry out the duties.

1. 2.Organizational Climate Variable (Y1)

Organizational Climate in this research referred to the perception or opinion of the respondent, about the situation or the internal working environment that felt by the facilitators in the National Program of Urban Community Empowerment in Lombok. These climates affect their work performance or behavior during conducting in organization.

Table 5. Average Scores and Categories of Organizational Climate Variables

\begin{tabular}{|l|l|l|l|}
\hline No. & Indicator Climate Organization & Average Score & Category \\
\hline 1. & Clarity of Assignment Duties and Responsibilities & 3.81 & Clear \\
\hline 2. & Clarity of Service Process and Target Facilitation & 3.67 & Clear \\
\hline 3. & Harmonious relationships with superiors and associates & 3.50 & Harmonious \\
\hline 4. & Social interaction with target communities & 3.79 & Harmonious \\
\hline 5. & Availability of Facilities and Work Equipment & 3.65 & Available \\
\hline 6. & Distribution and Allocation of Resources & 3.60 & Fair \\
\hline Average Score & 3.67 & Conducive \\
\hline
\end{tabular}

Source: Primary data processed

Climate or atmosphere felt by the companion who made the respondents in this study, viewed from 6 indicators. By looking at the six elements described above, it appears that the work atmosphere experienced by the companion can be declared "good". This means that the perceived organizational climate of Urban PNPM Mandiri 
in Lombok already can support them work.

1. 3. Organizational Commitment Variable (Y2)

Table 6. Average Scores and category of Organizational Commitment Variables

\begin{tabular}{|l|l|l|l|}
\hline No. & $\begin{array}{l}\text { Indicator } \\
\text { Organizational Commitment }\end{array}$ & Average Score & Category \\
\hline 1. & Equal value of vision, mission, goals and programs & 3.74 & Same Value \\
\hline 2. & Pride to be a member of the organization & 3.68 & Proud \\
\hline 3. & Allegiance to leaders and organizations & 3.72 & Loyal \\
\hline 4. & Willingness to accept the duties of the leadership & 4.02 & Ready \\
\hline 5. & Willing to sacrifice for the organization & 3.94 & Sacrifice \\
\hline 6. & Hope remains to be an organization member & 3.73 & Hope \\
\hline 7. & Feel the loss of leaving the organization & 3.82 & Stay \\
\hline Average Score & 3.81 & High Commitment \\
\hline
\end{tabular}

Source: Primary data processed

The organizational commitment in this study is a statement of attitudes and behaviors of the counselors, regarding to their participation and involvement as Urban PNPM Mandiri facilitators in Lombok Island. To measure the organizational commitment of respondents, the researcher used 7 indicators. By looking at the score of the seven elements of organizational commitment, it can show that they have "high commitment".

1. 4. Work Behavior Variable (Z)

In this study, Work Behavior is the assessment of superior or direct leadership of urban coordinator (Korkot) of urban PNPM Mandiri in Lombok Island toward behavior or deeds that are expected to be applied by the facilitators or as facilitators of activities in carrying out their job duties to facilitate the urban community as the object of the program. To measure work behavior, researchers used some form of work behavior as an indicator. Based on the data shows that the results of superior assessment (Korkot) on the work behavior of the facilitator (facilitator) shows a "good" value,

Table 7. Average Score and Category of Work Behavior Variable Indicators

\begin{tabular}{|l|l|l|l|}
\hline No. & $\begin{array}{l}\text { Indicator } \\
\text { Work Behavior }\end{array}$ & Average Score & Category \\
\hline 1. & Timeliness perform tasks & 3.78 & Efficient \\
\hline 2. & Discipline in work & 3.91 & Discipline \\
\hline 3. & Responsibility to the task & 3.82 & Big \\
\hline 4. & The spirit of completing the task & 3.97 & Spirit \\
\hline 5. & Creativity in work & 4.00 & Creative \\
\hline 6. & Politeness interacts and communicates & 4.00 & Polite \\
\hline \multicolumn{2}{|l|}{ Average Score } & 3.92 & Good \\
\hline
\end{tabular}

Source: Primary data processed

\section{Partial Least Square Analysis (PLS)}

Tests with the PLS approach are practical because these tests are not limited by having to meet normally distributed data and the limited number of data samples. Data analysis with PLS approach is done by evaluating measurement model and structural model.

\section{1.Individual Item Reliability Test}

By using PLS (Partial Least Square) version 2.0, and by calculating the algorithm (missing value: -0.1, data metric: mean 0 and variance 1, weighting scheme: path, max number iteration: 500, stop criterion accuracy: 0.0010) results as shown in Figures 1 and Table 12 which are the output path diagrams in Smart PLS 2.0.

The following table presents the results of Individual Item Reliability calculations to four variables, and from the output path diagram in Figure 1., it can be seen that the indicator has a factor loading value $<0.50$. Therefore, the indicators are removed in the research model. 
Table 8: Individual Item Reliability Research Variables

\begin{tabular}{|l|l|l|l|l|l|l|l|}
\hline \multicolumn{2}{|l}{$\begin{array}{l}\text { Leadership } \\
(\mathrm{X})\end{array}$} & \multicolumn{2}{l|}{$\begin{array}{l}\text { Climate Organization } \\
(\text { Y1 })\end{array}$} & \multicolumn{2}{l|}{$\begin{array}{l}\text { Individual } \\
\text { Commitment (Y2) }\end{array}$} & $\begin{array}{l}\text { Work Behavior } \\
(\text { Z) }\end{array}$ \\
\hline $\begin{array}{l}\text { Variable } \\
\text { Items }\end{array}$ & $\begin{array}{l}\text { Outer } \\
\text { Loading }\end{array}$ & $\begin{array}{l}\text { Variable } \\
\text { Items }\end{array}$ & $\begin{array}{l}\text { Outer } \\
\text { Loading }\end{array}$ & $\begin{array}{l}\text { Variable } \\
\text { Items }\end{array}$ & $\begin{array}{l}\text { Outer } \\
\text { Loading }\end{array}$ & $\begin{array}{l}\text { Variable } \\
\text { Items }\end{array}$ & $\begin{array}{l}\text { Outer } \\
\text { Loading }\end{array}$ \\
\hline X.1 & 0.437888 & Y1.1 & 0.757261 & Y2.1 & 0.331223 & Z.1 & 0.120751 \\
\hline X.2 & 0.065320 & Y1.2 & 0.880244 & Y2.2 & 0.808606 & Z.2 & 0.916824 \\
\hline X.3 & 0.070201 & Y1.3 & 0.817586 & Y2.3 & 0.801979 & Z.3 & 0.760815 \\
\hline X.4 & 0.687233 & Y1.4 & 0.800472 & Y2.4 & 0.739511 & Z.4 & 0.612426 \\
\hline X.5 & 0.034843 & Y1.5 & 0.819274 & Y2.5 & 0.698649 & Z.5 & 0.146019 \\
\hline X.6 & 0.747176 & Y1.6 & 0.178465 & Y2.6 & 0.854718 & Z.6 & 0.290538 \\
\hline & & & & Y2.7 & 0.759531 & & \\
\hline
\end{tabular}

Source: Primary data processed

2. 2.Internal Consistency Test

The value of composite reliability and Cronbach's alpha from research model after removal of an indicator having factor loading $<0.50$, can be seen Table 9 .

Table 9. Quality Criteria

\begin{tabular}{|l|l|l|l|l|}
\hline Variables & AVE & $\begin{array}{l}\text { Composite } \\
\text { Reliability }\end{array}$ & R Square & $\begin{array}{l}\text { Cronbachs } \\
\text { Alpha }\end{array}$ \\
\hline Leadership & 0.205453 & 0.725240 & & 0.662832 \\
\hline Climate Organization & 0.560089 & 0.872674 & 0.033833 & 0.815260 \\
\hline Organizational Commitment & 0.492719 & 0.864550 & 0.082664 & 0.815502 \\
\hline Work Behavior & 0.319131 & 0.664947 & 0.624673 & 0.762496 \\
\hline
\end{tabular}

Source: Primary data processed

It can be seen in Table 9 that the value of the composite reliability of each variable is higher than 0.70 as the cut-off value and so as the value of Cronbach's alpha has been already according to the recommended value $(>0$, 70 ). Therefore, the internal consistency has complied.

2. 3. Discriminant validity test

In this test, the first condition that must be compiled is that the value of AVE must be higher than 0,50 . It can be seen in Table 10 that the value of AVE in all variables $>0.50$ so that the first condition is met. Furthermore, the next requirement which must also be complied is the square root value of each variable AVE which must be higher than the correlation value with the other variables.

Table 10 is made to indicate that the AVE square root value (number marked "*" which is at the diagonal position) of each variable, is higher than the value of correlation among other variables (number which is in a row and one column with the AVE variable). The correlation value among these indicators is obtained by rounding correlation values in the SmartPLS output table which can be seen in the Appendix. Thus, the research model has met the discriminant validity.

Table 10. Latent Variable Correlation

\begin{tabular}{|l|l|l|l|l|}
\hline Variables & $\begin{array}{l}\text { Climate } \\
\text { Organization }\end{array}$ & Leadership & $\begin{array}{l}\text { Organizational } \\
\text { Commitment }\end{array}$ & $\begin{array}{l}\text { Work } \\
\text { Behavior }\end{array}$ \\
\hline Climate Organization & $0.748391 *$ & & & \\
\hline Leadership & 0.183938 & $0.453269 *$ & & \\
\hline $\begin{array}{l}\text { Organizational } \\
\text { Commitment }\end{array}$ & 0.759605 & 0.287513 & $0.701939 *$ & $0.564917 *$ \\
\hline Work Behavior & 0.662253 & 0.321366 & 0.774425 & \\
\hline
\end{tabular}

Source: Primary data processed

(*) root square of AVE

Based on the testing phase of the measurement model, it has been proved that the research model has fulfilled all the testing stages. Therefore, the structural model test stage can be performed. The structural model test is used to determine whether the hypothesis is accepted or not.

2. 4.Test of Model Structural

The value of R 2 generated as a result of the evaluation of this research model can be seen in the following table.

Table 11. R Square Model Value

\begin{tabular}{|l|l|l|}
\hline No. & Variables & R Square \\
\hline 1 & Climate Organization & 0.033833 \\
\hline 2 & Organizational Commitment & 0.082664 \\
\hline 3 & Work Behavior & 0.624673 \\
\hline
\end{tabular}

Source: Primary data processed 
The total data diversity that can be explained by this research model is measured by:

$\mathrm{Rm} 2=1-\mathrm{R} 12 . \mathrm{R} 22 . \mathrm{R} 32$

$\operatorname{Rm} 2=1-(0,034) 2 *(0,083) 2 *(0,625) 2$

$\operatorname{Rm} 2=1-0.001 * 0.007 * 0.390$

$\operatorname{Rm} 2=0.999$

In this case, Rm 2 has the same interpretation of the coefficient of determination (R2) in the regression analysis. Based on the results of the coefficient of determination total is approximately 0.999 which means that the diversity of data that can be explained by this research model is $99.9 \%$. Meanwhile, the rest is explained by other variables from other models which are not included in this research model.

2. 5. Test of Hypothesis

To determine the significance level of the path coefficient, the value of $t$ ( $t$-value) generated by running the Bootstrapping algorithm is used to determine whether the hypothesis is accepted or not. At the 0.05 significance level. The hypothesis will be supported if the t-value exceeds its critical value, ie 2,000298. The test results of significance level can be seen in Table 12, by summarizing the results of hypothesis testing with PLS approach. The value of the path coefficient and t-statistics is obtained from the SmartPLS output.

Figure 1. O utput Ppath Diagram

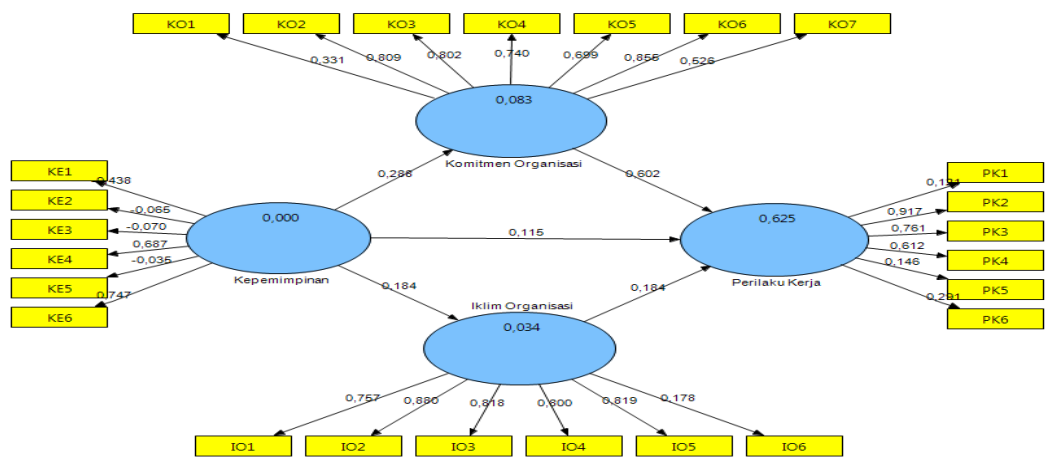

Source: SmartPLS output

1) The first hypothesis states "It is assumed that Leadership has a direct significant influence on the Organizational Climate on Urban PNPM Activities in Lombok Island ". The results of the analysis show that Leadership has a positive and significant influence of 0.184 on Organizational Climate. So it can be concluded that the first hypothesis can be accepted.

Table 12. Hypothesis Test Results

\begin{tabular}{|l|l|l|l|l|}
\hline Hypothesis & Coefficient & t statistics & t table & Information \\
\hline Hypothesis 1 & 0.183938 & 2.107032 & 2,000298 & Be accepted \\
\hline Hypothesis 2 & 0.287513 & 2.317015 & 2,000298 & Be accepted \\
\hline Hypothesis 3 & 0.114526 & 2.995107 & 2,000298 & Be accepted \\
\hline Hypothesis 4 & 0.184261 & 2.501346 & 2,000298 & Be accepted \\
\hline Hypothesis 5 & 0.601532 & 3,820130 & 2,000298 & Be accepted \\
\hline
\end{tabular}

Source: Primary data processed

2) The second hypothesis states "it is assumed that Leadership has a direct, significant influence on Organizational Commitment on Urban PNPM Activities in Lombok Island ". The results of the analysis show that Leadership has a positive and significant influence for 0.287 on Organizational Commitment. Consequently, it can be concluded that the second hypothesis is accepted.

3) The third hypothesis states "it is assumed that Leadership has a direct, significant influence on Work Behavior on Urban PNPM Activities in Lombok Island ". The results showed that Leadership has a positive and significant effect for 0.114 on Work Behavior. Therefore, it can be concluded that the third hypothesis is accepted.

4) The fourth hypothesis states that "It is assumed that Organizational Climate has a direct, significant influence on Work Behavior on Urban PNPM Activities in Lombok Island ". The results showed that Climate Organization has a positive and significant effect for 0.184 on Work Behavior. Therefore, it can be concluded that the fourth hypothesis is accepted.

5) The fifth hypothesis states that "It is assumed that Organizational Commitment has a direct, significant influence on Work Behavior on Urban PNPM Activities on Lombok Island ". The results showed that Organizational Commitment has a positive and significant effect for 0.601 on Work Behavior. Therefore, it can be concluded that the fifth hypothesis is accepted.

For more detail relationship between variables, with the results of data processing for each latent variable with the 
indicators, therefore it is obtained the output path diagram as shown in Figure 1.

\section{Interpretation}

3. 1.The influence of leadership on subordinate work behavior.

Based on the discussion of facilitator behavior which is the result of the direct supervisor's assessment of the elements of facilitator behavior, it shows that the facilitators have "well behaved" in performing their duties. Then the result of the analysis of the description of the leadership (coordinator of the city), which is perceived "good" by the facilitators.

Furthermore, from the analysis of Smart PLS shows that there is a positive and significant influence of leadership on the behavior of subordinates. Good leadership from the coordinator of the city has a considerable impact on changes in facilitator behavior. This means that if the better implementation of the functions of leadership, the better it can be ascertained the working behavior of facilitators, and conversely, the worse implementation of leadership functions in PNPM in Lombok Island, surely the worse work behavior of the facilitators.

The results of this study have supported the results of research conducted by some previous researchers including First, Mamik (2010) the researchers found that leadership style significantly influences employee performance and can be said that relationship style leadership with employee performance is positive and relatively strong enough. Secondly, Shahab (2010) found that there was a significant positive influence of Islamic leadership on Islamic performance. The better Islamic leadership was, then the better performance of Islamic employees. When the quality of Islamic leadership was further improved it will be able to have a positive impact on the employee's Islamic performance. Third, Hakim (2012), found that there was a positive and significant effect of leadership on the performance of Islamic employees. The results are interpreted if the quality of Islamic leadership can be implemented properly, then the employee's Islamic performance will be better.

The fourth researcher, in the same year Pradityo, et al (2012) found that there was a positive and significant influence of leadership on employee performance. Fifth, Sukardiyono (2013); the results of his research found that leadership had a positive and significant effect on employee productivity. Sixth, Wahyuni (2015) found that Leadership Style had the positive and significant influence on Employee Performance. It means the more appropriate leadership style, the higher the performance of employees, on the contrary, if the less appropriate leadership style, the lower performance of employees.

Whereas, there are different study results of the study above, which had previously been conducted by Susanto and Aisiyah (2010) found that Leadership did not have a significant effect on Employee Performance. Furthermore, Suparman, et al (2013) found that leadership had relatively less positive and insignificant to work performance. 3. 2. The influence of leadership on the Climate of the Organization.

From the results of the descriptive analysis or discussion of the variables above, that coordinators of the city have performed the leadership function well. It is certainly supported by the ability of knowledge, skills, attitudes and behaviors which has performed his duties function as a leader. Then, the working atmosphere experienced or felt by the companion otherwise "good".

Furthermore, from the test results Partial Least Square (Smart PLS) described earlier have shown that there is a significant, relatively large and significant influence of leadership on the Climate of the Organization. This means that "good" leadership (city coordinators) can create a "good" organization climate. Applying better implementation of leadership functions from the city coordinator, it will certainly make better working atmosphere or organizational climate perceived subordinates as well, contrary, if the implementation of leadership functions of the city coordinator is less, the working atmosphere or organizational climate who perceived the subordinates gets less or bad.

The findings support the previous research conducted by Fitri and Syamsir (2011) to conduct research on Indonesia State Owned Enterprise (BUMN) of PT PLN Solok; found that the results indicated that there was a positive and significant influence of leadership style on organizational climate.

3. 3. The influence of leadership toward organizational commitment.

The result of the analysis of the description of leadership variables perceived "good" by the subordinates. Therefore, subordinates' commitment toward the organization is categorized as "high commitment" stated by the subordinates. Furthermore, from the analysis of Partial Least Square (Smart PLS) shows that there is a positive influence and significant influence, from leadership to organizational commitment. This means that with the leadership of "good" city coordinators can make an organizational commitment from subordinates to "High". If it is good to implement the leadership functions of City Coordinators especially in mobilizing and directing subordinates, it will be able to make subordinates increasingly committed to remain in the organization. However, if the functions of leadership are not conducted maximally, subordinates' commitment will be low.

The first research found the similar result and supported the previous research conducted by: First, Raharjo and Durrotun (2006) conducted in Department of Religion of Kendal and Department of Religious of Semarang; the results found that five styles in leadership (participatory, achievement orientation, directive, supportive and influence) have positive and significant impact toward the employee performance. Secondly, Pramudito and 
Yunianto (2009), conducted a study in Rural Government Officer in Batang Sub-District, Batang District. The results found that leadership had a positive and significant impact toward the performance of officers. The implication of the findings is to improve the performance can be done through increased leadership conformity to members of the organization. Third, Shahab (2010) who conducted a study in Baitul Maal Wa Tamwil in Central Java Province, found that there was a significant positive influence of Islamic leadership toward Islamic performance. He assumed that the better implementing Islamic leadership, the better Islamic performance. If the leadership quality is further enhanced, it will be able to have a very positive impact on the employee's Islamic performance.

3. 4. The influence of organizational climate on work behavior.

The results of the discussion on organizational climate show a "good" work environment. Therefore, the behavior of assistant work assessed by the direct superior or city coordinator as the leader on some elements of work behavior indicates that the facilitators have behaved "good" in carrying out their duties.

Results of Partial Least Square (Smart PLS) analysis shows that the effect of organizational climate on coemployment behavior is positive, relatively large and significant. This means that the organizational climate which is assumed well by facilitators has notable meaning to change better work behavior. Since the influence is relatively large and significant, the improved work climate is better and it can improve the work behavior positively. In other words, if the organizational climate is perceived to be better and conducive, it is certain that the work behavior will also be better nevertheless if the organizational climate is felt less conducive, it is certain that the subordinate's work behavior will get worse.

This research found the similar result and was supported by the previous research conducted by: First, Pradityo, et al (2012) found that the organizational climate had a positive and significant impact toward the employee performance. Second, Sukardiyono (2013); found that the organizational climate had a positive and significant effect on employee productivity. Third, based on his research, the influence of organizational climate on employee performance has a positive and significant influence. It can be concluded that the better organizational climate, the higher employee's performance, otherwise if the organizational climate is less, the employee's performance will be worse.

3. 5.The influence of organizational commitment to work behavior.

As explained above, the organizational commitment of facilitators has been stated by the category of "high commitment ". Then the behavior of the facilitators' work assessed by the direct superior or city coordinator for some work behavioral elements, indicating that the subordinates have " good behavior " in performing their duties. The results of the statistical analysis show that the influence of organizational commitment to subordinate employee behavior is positive, big and significant. This means that high organizational commitment of the facilitators is able to improve their work behavior, or the higher commitment of the facilitators, the better behavior of those who work. By increasing the commitment of the facilitators, it can be ensured, followed by improved or improved work behavior.

The research found the similar result and was supported by the previous research conducted on the previous results that have been done by some researchers, among others: First, Pramudito and Yunianto (2009), found that leadership had a positive and significant impact toward the performance of village administration, the implication of his findings that to improve performance can be done through increased leadership conformity to members of the organization. Second, Shahab (2010) found that there was a significant positive influence of Islamic leadership toward Islamic performance. These results meant that the better Islamic leadership, the better performance of Islamic performance. When the quality of Islamic leadership is further improved it will be able to have a positive impact on the employee's Islamic performance. Third, Simbolon (2013) found that work commitment had a significant influence, either directly or indirectly to the performance of civil servant lecturers in Medan University of North Sumatra Province.

\section{Theory of Implications}

The first results found that the leadership has been influenced positively and significantly on organizational climate. Leadership as a process of influencing people through leaders' ability to implement the functions to achieve the goals. Climate organization is a perceived internal circumstance or atmosphere which affects the performance of employees within the organization. Good leadership and effective can create a climate of work better and conducive. Organizational climate viewed from aspects of the physical environment, social environment, and management systems, can vary depending on the role of the leaders. The findings of this research can find the explanation and understanding of the role of leaders in leadership that can influence (change) the climate of the organization towards the desired direction.

Results of the second study stated that the leadership has been influenced positively and significantly toward the organizational commitment. Commitment as a form of attitude and behavior of a person who has involved the organization. Through the leadership process that is perceived good and effective by employees as subordinates, it can make the employee has high organizational commitment. Otherwise, if it is considered and perceived by leadership less good and less effective, then the employee tends to lack of commitment to the organization. The 
findings of the research can add to the explanation and understanding that leadership can influence a person to commit to his organization.

The results of a third study found that the leadership has been influenced positively and significantly on work behavior. Job behavior is as a form of the results of the assessment of leadership or direct superior to the performance of subordinates (employees). Rules and processes of leadership that are considered and perceived to be effective, have an impact on better work performance as well. Otherwise, if the leadership is perceived and felt less effective, then tends to make or make performance subordinate work is not good. The results of this research can add to the explanation and understanding that the role of leadership is very important in an effort to improve employee performance.

The results of the fourth study found that organizational climate has influenced positively and significantly toward work behavior. Organizational climate in the physical environment, social environment, and management system can create a good atmosphere and conducive, can also occur the atmosphere is less good and less conducive. With a good and conducive organizational climate can influence the work behavior of subordinates to the better, and vice versa that a poor organizational climate and less conducive, can impact on subordinate work behavior to be bad. The results of this study can add to the explanation and understanding that the relationship as well as the influence of the resulting organizational climate on the behavior of subordinates.

The fifth research result found that organizational commitment has influenced positively and significantly toward work behavior. Organizational commitment as a form of attitude and behavior of a high-low nature. Then the behavior of work as a form of work performance that is good-bad. The higher organizational commitment of employees improved work behavior, on the contrary, the lower organizational commitment of employees can influence the increasingly poor or bad work behavior. The results of this research can add to the explanation and understanding that the relationship as well as the impact of the organizational commitment from employees to their work behavior.

\section{Managerial Implications}

The results of the analysis of leadership influence on organizational climate, organizational commitment, and work behavior show there is a positive and significant influence. The result can be interpreted that with better leadership (through the implementation of operational functions by leaders), it is certain that the organizational climate is getting better, the employees' commitment to the organization is higher, and the employee's behavior is getting better (in this case the assistant to the National Program for Urban Community Empowerment in Lombok Island). Then by considering the results of the descriptive analysis of each variable, it can be explained clearly the implications of these findings. Leadership in this study is the perception of subordinates (facilitators / companion) to the attitude and behavior of leaders (city coordinators) on the national program of community empowerment in the island of Lombok. The results of the companion assessments made by respondents to the leadership of Korkot in every City / Regency on Lombok Island show leadership that is categorized as "good"; meaning that the City Coordinators have performed their leadership function well.

The leadership of the Coordinators of the City can be improved through the improvement of various activities that have not been optimally implemented. The coordinators can seek advice and opinions from subordinates (facilitators), as they work in the field and link their activities with the attitude and behavior of their leaders in carrying out their functions. Companions see, hear and feel directly the manner or behavior of leaders in giving orders, suggestions, directions and policies issued to run or complete activities on the ground.

The impact of better leadership can certainly create a better organizational climate. The organizational climate in this study is the opinion of the respondents about the internal working environment or atmosphere felt by the companions/facilitators in the National Program of Urban Community Empowerment in Lombok Island. Organizational climate as the working atmosphere experienced by the companion can be declared condition "good" which means that the perceived organizational climate of the PNPM Mandiri Urban companion in the island of Lombok already can support them to work.

This organizational climate can be enhanced by the leaders through the involvement of subordinates (facilitators) in describing the tasks and responsibilities of the companion more clearly, clarifying the process of service process and facilitation of target communities, creating a more harmonious atmosphere between the coordinator with the facilitator. In addition, the coordinator takes into account the necessary facilities and equipment at the time of operation, as well as the allocation and distribution of resources in a fair manner.

Likewise, the better leadership will certainly increase the commitment of subordinates to the better organization as well. The organizational commitment in this study is a statement of attitudes and behaviors of the companions, in relation to their participation and involvement as PNPM Mandiri Urban facilitators in Lombok Island. Based on the opinion of the companions as the respondent, they have a great commitment.

To increase the commitment of counselors, the city coordinator as a leader should try to carry out its function better, so that they feel that Urban PNPM Mandiri is a very suitable place to work according to the value of their life so they feel the pride of working there. They will be willing to work and receive duties at all times from their bosses, and they hope to remain part of the organization and will not leave the workplace. 
The results of the study which states that the better leadership can certainly improve the subordinate work performance better as well. In this research, the Work Behavior as a representation of the work performance or coperformance is the assessment of the superior or direct leader that is the coordinator of the city (coordinator of the city) Urban PNPM Mandiri in Lombok Island against the form of work behavior expected from the facilitators of field activities in carrying out their job duties facilitating urban community that became the object of the program. The results of the assessment of the city coordinator on the work behavior of the facilitator / facilitator show "good behavior".

The behavior value of companions' performance can certainly be enhanced through several efforts of city leaders/coordinators. Running a leadership function well than ever, coordinators can demonstrate exemplary and politeness in interacting and communicating with companions/facilitators as their subordinates. Coordinators should focus more on creating an improved organizational climate and should strive to increase subordinate commitment to the organization. Coordinators pay attention to the workload of companions' duties and with the magnitude of the awards they receive. And in conducting supervision and providing evaluation should be educational feedback.

\section{Conclusion}

Based on the overall statement above, it is concluded that the work behavior of facilitators as Urban PNPM Mandiri facilitators in Lombok Island is "good ". This has been supported by the cooperative of the city coordinator in each of the districts, who perceived the facilitators as "good ". Then the organizational climate felt by the facilitators in work is also "good "; as well as attitudes and behaviors that demonstrate their commitment to work within an organization show a "high" commitment.

The result of statistical analysis (Partial Least Square (PLS)), that relationship and the influence between variables show: (1) Leadership has a positive, relatively large, and significant impact toward the Climate Organization. (2) Leadership has a positive, significant, and significant influence toward the Organizational Commitment. (3) Leadership has a positive, relatively small, and significant impact on Work Behavior. (4) Organizational Climate has a positive, relatively large, and significant impact on Work Behavior. (5) Organizational Commitment has a positive, big, and significant influence on Work Behavior.

\section{References}

Antonio, M S. (2007). Muhammad SAW The Super Leader Super Manager; Jakarta; Tazkia Multimedia \& ProLM Centre.

Desianty, S. (2006). Pengaruh Gaya Kepemimpinan Terhadap Komitmen Organisasi Pada PT Pos Indonesia (Persero) Semarang. Jurnal Studi Manajemen \& Organisasia. 2006, Vol 2, No.1,

Fitri, S. E.; Syamsir. (2011). Pengaruh Gaya Kepemimpinan terhadap Iklim Kerja Organisasi pada PT. PLN Cabang Solok; DEMOKRASI. 2011, Vol. X, No. 2, Th. 2011, s. 159-174.

Ghozali, I. (2006). Struktural Equation Modeling, Metode Alternatif dengan Partial Least Square (PLS), Semarang, Badan Penerbit Universitas Diponegoro.

Gibson, J. L.; Ivancecevich, J. M. and Donnelly, J. H. Jr, (1996). ORGANISASI, Perilaku, Struktur, Proses, Jilid I dan II, Edisi Kedelapan, Jakarta, Binarupa Aksara.

Hakim, A. (2012), The Implementation of Islamic Leadership and Islamic Organizational Culture and Its Influence on Islamic Working Motivation and Islamic Performance PT Bank Mu'amalat Indonesia Tbk Employee in the Central Java. Asia Pacific Management Review. 2012, Vol. 17, No. 1, s. 77-90.

Hanafiah, M. A. (2016). Pengaruh Kepemimpinan dan Kerjasama Tim Melalui Kepuasan Kerja terhadap Kinerja Pendamping Kegiatan Program Nasional Pemberdayaan Masyarakat Perkotaan di Nusa Tenggara Barat, Tesis, Program Magister Manajemen, Pascasarjana Universitas Mataram

Lina, D. (2014). analisis Pengaruh Kepemimpinan dan Budaya Organisasi Terhadap Kinerja Pegawai Dengan Sistem Reward Sebagai Variabel Moderating. Jurnal Riset Akuntansi dan Bisnis. 2014, Vol 14, No. 1, s. 77 97.

Luthans, F. (2006). Perilaku Organisasi”, Edisi Sepuluh, Terjemahan : Vivin Andhika Yuwono, dkk; Penerbit Andi, Yogyakarta.

Mahri, A. J. W. (2014). Kepemimpinan Kepala Sekolah Pengaruhnya Terhadap Kompetensi, Motivasi, Dan Kepuasan KerjaGuru Seta Implikasinya pada Kinerja Guru. Kontigensi. 2014, Vol. 2, No. 1, s. 39-54.

Mamik. (2010). Pengaruh Gaya Kepemimpinan, Motivasi Kerja, dan Komitmen Organisasi Terhadap Kinerja Karyawan", Majalah Ekonomi, Wahana Karya Ilmiah : Bidang Ilmu Ekonomi, Manajemen dan Akuntansi, Tahun XX, No. 1 April 2010, Terakreditasi No. 43/DIKTI/Kep/2008.

Pradityo, N. A.; Rodhiyah, and Saryadi. (2012). Pengaruh Kepemimpinan dan Iklim Organisasi Terhadap Kinerja Karyawan PT. Telkom Indonesia Semarang. Retrieved from; http://download.portalgaruda.org/ article.php? article $=74777 \&$ val $=4721$

Luksono, P.; and Askar, Y. (2009). Pengaruh Kepemimpinan dan Motivasi Terhadap Kenerja Dengan Komitmen 
Organisasional Sebagai Mediasi (Studi Pada Perangkat Desa Se Kecamatan Batang Kabupaten Batang. Telaah Manajemen/ TEMA. 2009, Vol. 6, No. 1, s. 1-18.

Raharjo, S. T.; and Durrotun, N. (2006). Pengaruh Gaya Kepemimpinan Terhadap Kepuasan Kerja, Komitmen Organisasi dan Kinerja Karyawan (Studi Empiris Pada Departemen Agama Kabupaten Kendal dan Departemen Agama Kota Semarang. Jurnal Studi Manajemen \& Organisasi. 2006, Vol. 3, No. 2, s. 69-81.

Robbins, S. P. (2006). PERILAKU ORGANISASI, Vol. I and II, Ed. 9, Jakarta, PT. Indeks Kelompok Gramedia

Shahab, M. A. (2010). Implementasi Kepemimpinan dan Komitmen serta Pengaruhnya Terhadap Kepuasan Kerja dan Kinerja Karyawan Perspektif Islam. JRBI. 2010, Vol. 6, No. 2, s. 184-200.

Sahat, S. (2013). Pengaruh Kepemimpinan Visioner, Motivasi, dan Kompetensi Terhadap Budaya Kerja dan Komitmen Serta Implikasinya pada Kinerja Dosen. Kontigensi. 2013, Vol. 1, No. 2, s. 78-88.

Sobirin, A. (2009). Budaya Organisasi, Pengertian, Makna dan Aplikasinya dalam Kehidupan Organisasi, Edisi Kedua, UPP STIM YKPN, Yogyakarta

Sukardiyono. (2013). Pengruh Iklim Organisasi, Kepemimpinan, dan Budaya Organisasi Terhadap Produktivitas Kerja Pegawai Pada Badan Kesatuan Bangsa, Politik dan Perlindungan Masyarakat Kabupaten Kediri. Jurnal OTONOMI. 2013, Vol. 13, No. 1, s. 1-8.

Suparman, L..; Nasir, M. and Suryatni M. (2013). Analisis Pengaruh Kompetensi dan Kepemimpinan Kepala Sekolah Terhadap Kepuasan kerja dan Prestasi Kerja Guru (Studi Pada Madrasah Aliyah Negeri dan Madrasah Tsanawiyah Negeri di Kota Mataram). Jurnal Riset Manajemen - JRM. 2013, Vol. 13 No. 2 ,

Suparman, L..; Nasir, M. and Suryatni M. (2015). Analisis Pengaruh Kepemimpinan Terhadap Komitmen Organisasi, Motivasi Kerja dan Kinerja Organisasi (Studi Pada Badan Amil Zakat Daerah Kabupaten/ Kota di Pulau Lombok. Jurnal Riset Manajemen - JRM. 2013, Vol. 15, No. 1,

Supriyono, R. A. (2005). Pengaruh Komitmen Organisasi, Keinginban Sosial dan Asimetri Informasi Terhadap Hubungan Antara Partisipasi Penganggaran Dengan Kinerja Manajer Di Indonesia. Jurnal Ekonomi dan Bisnis Indonesia. 2015, Vol. 20, No 1.

Susanto, H., and Aisiyah, N. (2010). Analisis Pengeruh Kepemimpinan dan Budaya Kerja dengan Motivasi Sebagai Variabel Intervening Terhadap Kinerja Karyawan di Kantor Pertanahan Kabupaten Kebumen. Jurnal Magistra. 2010, Vol. 74 No. 1

Wahyuni, R. (2015). Pengaruh Gaya Kepemimpinan, Iklim Organisasi, Dan Kemampuan Kerja Terhadap Kinerja Karyawan PT. Garuda Indonesia Padang. Psyche 165 Journal. 2015, Vol. 8, No. 2,

Wirawan. (2008). Budaya dan Iklim Organisasi, Teori Aplikasi dan Penelitian, Cetakan Kedua, Salemba Empat, Jakarta

Yukl, G. (2005). Kepemimpinan Dalam Organisasi, Edisi Kelima, Terjemahan: Budi Supriyanto, Jakarta, PT. Indeks Kelompok Gramedia. 